\title{
La imagen del judío en la España medieval
}

\author{
Enrique Cantera Montenegro*
}

\begin{abstract}
RESUMEN
Desde fechas tempranas de la Edad Media fue configurándose $y$ difundiéndose una imagen peyorativa de los judios, expresión de la profunda antipatía que hacia ellos sentía la población mayoritaria cristiana. La imagen del judío medieval, que fue conformada a lo largo de los siglos por los derechos civil y canónico, consiste

en un estereotipo, con rasgos muy semejantes entre los diferentes ámbitos geo-históricos del Occidente europeo. Lejos de ser un reflejo fiel de la realidad,

guarda una estrecha relación con el lugar que la minoría hebrea ocupaba en

la conciencia colectiva cristiana medieval; de este modo, pese a que los judíos constituian un grupo heterogéneo desde los más diversos puntos de vista socio-económico, religioso o cultural, aparecían homogeneizados a través de diversos rasgos que el subconsciente de la población mayoritaria convertía en universales.

\section{ABSTRACT}

Since the early beginning of the Middle Ages, the jewish bad image spread among the christian - majority population as an expression of a deep feeling of rejection towards them. The middle ages jewish image is a result of the influence of the civil and religious laws through centuries and consists on a stereotype with very similar features among the different geo-historical regions of Western Europe. Far from reflecting the true reality, this attitude was closely linked to the general feeling of middle ages christians towards the jewish minority. Thus, although jews were different between themselves under a variety of points of view, socio-economic, religious or cultural, they were considered in the same way by an unconscient process of generalisation in the majority of the population.

Among the most significant features attributed to the jewish minority, the
\end{abstract}

* UNED. 
Entre los rasgos que identificaban hacia el exterior a la minoría hebrea se escogian los más llamativos: determinados rasgos físicos y del carácter; el uso de ciertas prendas de vestir; el ejercicio de algunas actividades profesionales, principalmente el préstamo con interés, y la posesión de enormes riquezas; o la práctica de ciertos crímenes rituales.

Esta homogeneización del grupo actuaba como un auténtico estigma, $y$

explica en buena medida la actitud hostil hacia la minoria hebrea, tanto desde un punto de vista teórico como en la práctica.

En este trabajo se analizan los distintos argumentos que conformaron la imagen del judío medieval, a su vez

generadores de odio hacia la población hebrea y legitimadores de las actitudes hostiles de la población mayoritaria. most outstanding of all were chosen: the physical appearance, the behaviour, the use of certain clothes, some professional activities like banking, their enormous wealth and the practice of ritual murders. This homogeneous feeling about that group acted as a real stigma and explains well the hostile attitude towards the jewish minority, both under the theoretical and practical point of view.

In this report, the different elements that built the image of the jews during the middle ages are analyzed. They have contributed, in an important way, to feed the hate towards the jewish and to legitimate the hostile attitude of the majority of the population.

\section{INTRODUCCIÓN}

Pese a los considerables avances que en los últimos decenios han experimentado los estudios y las investigaciones acerca de la historia de la minoría judía en la España medieval, todavía no han sido suficientemente analizados los diferentes y complejos aspectos relativos a la mentalidad y al mundo de las imágenes. Sin embargo, es indudable que se trata de un tema de trascendental importancia para profundizar en el conocimiento de las concepciones mutuas entre la mayoría cristiana y la minoría judía.

Son éstas cuestiones que se encuentran en estrecha relación con temas como el de el Otro y el de la imagen en la Historia, que ocupan un lugar cada vez más relevante en la actual producción historiográfica, en estrecha conexión con la llamada historia de las mentalidades.

Haciendo uso de las palabras del profesor Benito Ruano en su magnífico discurso de recepción en la Real Academia de la Historia, por el Otro hay que entender «el múltiple sujeto que se presenta a los ojos de una cultura, de una sociedad, de un estado, de una generación, de un grupo hu- 
mano cualquiera, o, simplemente, de un individuo, como alguien o algo perteneciente a su propia naturaleza, pero al mismo tiempo radicalmente distinto de sí mismo". La imagen histórica sería, por su parte, la comprensión que un determinado sujeto histórico, generalmente colectivo (una cultura, una sociedad, un estado), tendría en su tiempo de sus homogéneos contrapuestos ${ }^{1}$. Estas figuras o imágenes son creadas en función de determinados condicionamientos, y dan lugar a tomas de actitud, más o menos radicales, en relación con el Otro.

Parece fuera de cualquier duda que toda imagen histórica conlleva un margen de error, como resultado de la distancia existente entre la propia realidad y la imagen de ella producida por quien la percibe. Pese a todo, las imágenes poseen una virtualidad histórica, por cuanto dan lugar a acontecimientos históricos reales; no en vano, creadas de forma inconsciente o deliberada, pueden ser provocadoras de sentimientos de adhesión o de repulsión hacia el sujeto al que se refieren ${ }^{2}$.

Otro estudioso de estas cuestiones, Ron Barkai, considera la imagen como una expresión simbólica literal de la realidad; así, pues, no se trata de una descripción objetiva de la realidad, sino del reflejo de las concepciones subjetivas de quienes la conforman ${ }^{3}$. Siguiendo el modelo propuesto por este historiador hebreo, el estudio de las imágenes puede permitir, en relación con el tema de la minoría judía, una mejor comprensión de la mentalidad de hostilidad entre las comunidades cristiana y judía en la España medieval, desde una óptica que difícilmente podría ser definida en términos jurídico-legales, económico-sociales o culturales. $Y$ de ahí su enorme interés.

En este trabajo se abordará parcialmente el estudio de la imagen del judío en la España medieval, centrándose en concreto en el análisis de los rasgos más destacados que conformaron una imagen peyorativa que perduró a través de los siglos, hasta prácticamente la actualidad.

\section{EL OTRO JUDÍO}

Junto al musulmán, el judío es el Otro religioso por excelencia del cristiano en la España medieval; aunque menos temido que aquél desde el

1 Real Academia de la Historia, De la Alteridad en la Historia. Discurso leido el día 22 de mayo de 1988 en la recepción pública de D. Eloy BENITO RUANO, y contestación por el Excmo. Sr. D. Antonio Rumeu de Armas. Madrid, 1988, págs. 15-16.

2 Eloy Benito Ruano, De la Alteridad en la Historia, págs. 23-24.

3 Ron Barkal, Cristianos y musulmanes en la España medieval. El enemigo en el espejo. Madrid. Rialp, 1984, pág. 11. 
punto de vista político-militar, es igualmente rechazado y, quizá, más odiado aún en el orden espiritual, como resultado de sus comunes orígenes históricos y teológicos ${ }^{4}$.

La aversión cristiano-judía tiene unos orígenes remotos, consustanciales al proceso de conformación de la doctrina cristiana y al propio desarrollo de su comunidad ${ }^{5}$. Muy posiblemente el Adversus ludaeos de Tertuliano (200-201 d.C.) sea el primer tratado en el que es ya patente una autoafirmación cristiana sustentada en la polémica antijudia.

El odio teológico de los primeros apologistas cristianos frente al judaísmo, se transformó a lo largo de los siglos medievales en un odio sociológico, que degeneró en un auténtico odio racial a fines de la Edad Media y en los primeros tiempos de la Modernidad ${ }^{6}$.

Pero quizá la característica más señalada del antijudaísmo sea su universalidad y su permanencia en el tiempo, de forma que es una realidad presente en los más diversos ámbitos geo-históricos y en todas las épocas. Aunque son varias las causas que pudieron contribuir al rechazo generalizado hacia la población hebrea en época medieval, probablemente la que más peso tuvo fue, además de su diferenciación en materia religiosa, su decidida voluntad de conservar una identidad propia en el seno de la sociedad mayoritaria en la que se insertaba, con el fin de evitar su disolución como grupo social propio y diferenciado.

En España, el problema judío se plantea cuando aún no está definitivamente conformada la sociedad hispano-visigoda; la legislación antijudía de Sisebuto (612-621) constituye el primer paso en un proceso que condujo, en fases sucesivas, a la discriminación legal positiva, a la servidum-

\footnotetext{
Eloy Benito Ruano, De la Alteridad en la Historia, págs. 67-68.

5 Para el estudio de las conexiones entre judaísmo y cristianismo, así como de las raíces históricas del confiicto medieval entre una y otra religiones, es de gran interés el libro de Emilio Mitre Fernández, Judaísmo y Cristianismo. Raíces de un gran conflicto histórico. Madrid. Istmo, 1980. En la misma línea están los excelentes estudios de Bernhard BLUMENKRANZ, Les auteurs chrétiens latins du Moyen Âge sur les juits et le judaïsme, Paris, 1963, D. BERGER, The JewishChristian Debate in the Middle Ages, Philadelphie, 1979, y Lellia CaACCo RugGINI, «Pagani, ebrei e cristiani: Odio sociologico e odio teologico nel mondo antico", en Gli Ebrei nell'Alto Medioevo, XXVI Settimana di Studi del Centro Italiano di Studi sull'Alto Medioevo (Spoleto, 1978), Spoleto, 1980, págs. 15-101.

Centrados en el caso español, son particularmente útiles el libro coordinado por Carlos del Valle Rodríguez, La controversia judeocristiana en España. (Desde los origenes hasta el siglo XIII). Homenaje a Domingo Muñoz León, Madrid, Consejo Superior de Investigaciones Científicas, 1998, y el amplio estudio de Fausto PARENTE, "La controversia tra ebrei e cristiani in Francia e in Spagna dal VI al IX sécolo", en Gli Ebrei nell'Alto Medioevo, XXVI Settimana di Studi del Centro Italiano di Studi sull'Alto Medioevo (Spoleto, 1978), Spoleto, 1980, págs. 529-639.
}

5 Eloy Benito Ruano, De la Alteridad en la Historia, pág. 67. 
bre, al destierro e, incluso, a la persecución abierta en los tiempos de Egica (687-702).

Más tarde, la presunta colaboración judia con la invasión musulmana de la Península lbérica, que se conservaba muy viva en la memoria colectiva de los mozárabes y que, a su vez, éstos transmitieron a los reinos hispano-cristianos del norte, serviría frecuentemente para justificar el profundo recelo que se sentía hacia la población hebrea; este argumento se utilizaba también como una prueba manifiesta de la hostilidad que los judíos sentían hacia los cristianos y el cristianismo. Las semejanzas culturales y lingüísticas entre musulmanes y hebreos avalaban a los ojos de los cristianos la sospecha de una alianza, de forma que los judíos venían a ser una especie de enemigo infiltrado.

Como resultado de este sentimiento antijudio, desde fechas tempranas de la Edad Media comenzó a configurarse y a difundirse una imagen peyorativa de los judíos, expresión de la profunda antipatía que hacia ellos sentía la población mayoritaria cristiana, y que perduró hasta tiempos bastante recientes. Muy expresiva al respecto es la caracterización que de los judíos hacía, todavía en el siglo XVII, el inquisidor Escobar del Corro en su Tractatus de Puritate et Nobilitate probanda: los hebreos y sus descendientes eran para él

\begin{abstract}
"abyectos, infames, sediciosos, cúpidos, avaros, perniciosos para la comunidad de los hombres, sospechosos de herejia, inquietos, ambiciosos y pérfidos, embusteros y falsos, incrédulos, cogotes pelados, propagadores del mal, egoístas, arrogantes, orgullosos, blasfemos, desobedientes a sus padres, ingratos, sacrílegos, incapaces de amar, violentos, criminales, incontinentes, despiadados, crueles, traidores, lascivos, hinchados de vanidad, devolvedores de mal por bien, supersticiosos, punibles y sediciosos, amigos de la venganza y enemigos de los cristianos" ?.
\end{abstract}

El arte figurativo cristiano medieval refleja fielmente la imagen que de los judíos existía en toda la Europa occidental y que, en buena medida, coincidía con el retrato que de ellos hacía unos siglos después el inquisidor Escobar del Corro. Es éste un tema que ha analizado con maestría Bernhard Blumenkranz, para quien el arte figurativo cristiano es un auténtico "espejo del destino judío" ${ }^{8}$. Este autor pone de manifiesto la eficacia apologética que a lo largo de la Edad Media tuvo la imagen, como arma

7 Eloy Benito Ruano, De la Alteridad en la Historia, pág. 72.

8 Bernhard BlumenkaAnz, subtitula el capítulo introductorio de su obra Le juif médiéval au miroir de l'art chrétien (Paris. Études Augustiniènnes, 1966), con un significativo encabezamiento: "L'art chrétien: un miroir du destin juif" (pág. 11). 
aún más efectiva que la palabra en la controversia y en la predicación destinada a un pueblo que, en su inmensa mayoría, era analfabeto. Un ejemplo ilustra a todas luces esta afirmación: cuando a mediados del siglo $X V$ fray Alonso de Espina pregunta a unos monjes franceses en qué se fundamentaban sus afirmaciones acerca de que los judíos de Francia habían sido expulsados en 1306 a causa de las usuras y de las profanaciones de que serían autores, le contestan que en Francia todo el pueblo sabía que esto había sido así, pues lo conocían a través de las representaciones plásticas de numerosas iglesias ${ }^{9}$.

En definitiva, mediante unas imágenes estereotipadas que comprenden rasgos físicos (nariz larga y ganchuda), actitudes determinadas (sonrisa sardónica, mirada malévola), o el ejercicio de actividades profesionales infamantes (en particular, el préstamo usurario o con interés), se personifica en el judío la idea del mal absoluto y, con frecuencia, se sugiere la presencia diabólica en él ${ }^{10}$.

\section{ARGUMENTOS CONFORMADORES DE LA IMAGEN DEL JUDÍO}

La imagen del judio medieval fue conformada a lo largo de los siglos por los derechos civil y canónico, y tiene su más clara expresión en las argumentaciones antijudías contenidas en textos jurídicos, canónicos o doctrinales. Consiste en un estereotipo, en una imagen de la realidad distorsionada o, cuando menos, exagerada, con rasgos muy similares entre los diferentes ámbitos geo-históricos del Occidente europeo, y que quedó prácticamente conformada en el siglo XIII ${ }^{11}$. Como acertadamente señala

9 Fray Alonso DE EsPINA, Fortalitium fidei, Lib. III, Cons. IX, fols. 167-167 v. Citado por Bernhard Blumenkranz, Op. cit., pág. 27

io Véase al rospecto el estudio de J. Trachtenberg, The devil and the Jews. The medieval conception of the Jew and its relations to modern antisemitism. Yale, 1943.

Centrado en la Inglaterra medieval, es interesante el trabajo de Cecil RorH, «Portraits and Caricatures of Medieval English Jews", en Essays and Portraits in Anglo-Jewish History, Philadelphie, 1962.

11 Son interesantes sobre este particular, entre otros, los estudios de Julio CARO BAROJA, Los judios en la España Moderna y Contemporánea, Madrid, Istmo, 1978 (2 ed.), 3 vols. (en concreto el capítulo 4 de la Primera Parte de la obra, titulado «El carácter judio según la doctrina antisemita tradicional», vol. I, págs. 91-107); León Poliakov, Historia del antisemitismo. De Cristo a los judios de las Cortes, Barcelona, Muchnik Editores, 1986 (en concreto el capítulo VII, titulado "La imagen del judío", págs. 121-160); y José María MONSALvo ANTON, Teoría y evolución de un conflicto social. El antisemitismo en la Corona de Castilla en la Baja Edad Media, Madrid, Siglo XXI, 1985 (en concreto el capítulo 4, titulado "ldeología antijudía: Argumentación hostil y estereotipo", págs. 107-134), y “Mentalidad antijudía en la Castilla medieval", en Xudeus e conversos na Historia (Carlos Barros, ed.), Santiago de Compostela, La Editorial de La Historia, 1994, vol. I, págs. 21-84. 
Julio Caro Baroja, «el judío típico no es el judío corriente, sino más bien un arquetipo" ${ }^{12}$.

Lejos de ser un reflejo fiel de la realidad, la imagen del judío entra en el terreno de la ideología, y tiene mucho que ver con la historia de las mentalidades y la psicología social, que analizan el comportamiento de los grupos humanos. De este modo, guarda una estrecha relación con el lugar que la minoría hebrea ocupa en la conciencia colectiva cristiana, de forma que de un grupo heterogéneo desde los más diversos puntos de vista socio-económico, religioso o cultural, se extraían determinados rasgos que, aunque sólo fueran propios de algunos individuos, se convertían en universales por el subconsciente de la población mayoritaria, homogeneizando hacia el exterior a todo el colectivo hebreo.

Entre los rasgos que personifican hacia el exterior a la minoría judía se escogen los más llamativos o los que, al menos aparentemente, resultan más señalados: determinados rasgos físicos y del carácter; el uso de ciertas prendas de vestir; el ejercicio de algunas actividades profesionales, principalmente el préstamo con interés; la posesión de enormes riquezas; o la realización de algunos crímenes rituales con una supuesta finalidad religiosa. Esta homogeneización del grupo actuaba como un auténtico estigma, permitiendo la fácil identificación del judío; al mismo tiempo, la imagen conformada por la sociedad hispano-cristiana explica en buena medida su actitud hostil en relación con los judíos, tanto desde un punto de vista teórico como en la práctica ${ }^{13}$.

El estereotipo del judío medieval se corresponde con unos determinados valores, en los que, con frecuencia, se sustentarán las argumentaciones antijudías. Julio Caro Baroja señala que a fines de la Edad Media existían cuatro grandes tipos de argumentos por los que los judíos eran odiados, y que, en conjunto, conformaban la imagen que de ellos tenían sus contemporáneos cristianos:

1. Argumentos de carácter religioso, entre los que sobresale la acusación de deicidio.

2. Argumentos de carácter económico, como el afán desmedido de riquezas y la práctica de ciertas actividades profesionales, principalmente el préstamo con interés.

3. Argumentos de carácter psicológico, como la soberbia y la posesión de una inteligencia particular.

12 Julio Caro Baroja, Op. cit., vol. I, pág. 94

13 José M." Monsalvo Antón, Op. cit, págs. 117-118. 
4. Argumentos de carácter físico, de forma que los judíos presentarían unos rasgos externos propios y diferenciadores que, en conjunto, le conferian un aspecto ingrato ${ }^{14}$.

Estos argumentos, más bien causas del odio contra los judíos, constituian una justificación o legitimación de las actitudes hostiles de los cristianos hacia la minoría hebrea. Partiendo de unas ideas esquemáticas, se construye el estereotipo, que guarda una estrecha relación con actitudes prejuiciadas. Para José M. ${ }^{a}$ Monsalvo, los cristianos hispanos de época medieval interpretaban la posición de sus contemporáneos judíos mediante la "ideología", que no sería una simple interpretación imaginaria de la conciencia cristiana, sino que, yendo mucho más lejos, cumpliría un doble objetivo:

1. Proporcionar, de forma consciente, una imagen de los judíos más o menos deformada, $y$

2. Propiciar la discriminación legal y social de los judíos, al agudizar el odio de la población mayoritaria cristiana hacia ellos ${ }^{15}$.

Para profundizar en el conocimiento de la imagen del judío en la España medieval puede acudirse a diversos tipos de fuentes, entre las que destacan las de contenido jurídico; las literarias ${ }^{16}$, con particular referencia a los tratados de polémica doctrinal ${ }^{17}$, así como a narraciones moralizantes, colecciones de milagros ${ }^{18} 0$ "exempla»; las artísticas; o las propiamente documentales, entre las que tienen un especial interés los sermonarios y los cánones de sínodos y concilios provinciales.

14 Julio Caro Baroja, Op. cit., vol. I, pág. 104.

15 José M. Monsalvo Antón, Op. cit., págs. 108-109.

16 Entre los estudios dedicados a analizar la figura de los judios en distintas obras literarias pueden ser destacados el de Albert I. BAGBY, "The Jew in the Cantigas of Alfonso X el Sabio", en Speculum, 46 (1971), págs. 670-688, el de V. HATTON y A. MACKAl, cAnti-semitism in the Cantigas de Santa Maria", en Bulietin of Hispanic Studies, 61 (1983), págs. 189-199, y el de Xosé FILGuEIRA VAlverde, "Os xudeus nas Cantigas de Santa Maria", en Xudeus e Conversos na Historia (Carlos Barros, ad.), vol. I, págs. 246-263, sobre las Cantigas de Santa María de Alfonso X el Sabio; el de Francisco Cantera Buagos, "El Cancionero de Baena: judíos y conversos en él», en Sefarad, XXVII (1967), págs. 71-112; o los de Nicasio SalVADOR MIGUEL, "Reflexiones sobre el episodio de Rachel y Vidas en el Poema de Mio Cid", en Revista de Filología Española, LIX (1977), págs. 183224, y "Unas glosas más al episodio de Rachel y Vidas en el Cantar de Mío Cid", en Serta Philoiogica F. Lázaro Carreter, Madrid, Cátedra, 1983, págs. 493-498.

17 Son paradigmáticos a este respecto la Sentencia-Estatuto de Pero Sarmiento y el Memorial del bachiller Marcos García de Mora, "Marquillos de Mazarambroz", publicados y estudiados por Eloy Benito Ruano, Los orígenes del problema converso, Barcelona, El Albir Universal, 1976, así como el Fortalitium fidei de fray Alonso de Espina.

18 Véase el trabajo de J. SAUGNIEUX, “El antisemitismo de Berceo", en Literatura y espiritualidad españolas, Madrid, Prensa Española, 1974, págs. 143-188, acerca de Los Milagros de Nuestra Señora de Gonzalo de Berceo. 
La mayor dificultad radica en que la práctica totalidad de las fuentes disponibles proceden de la élite ilustrada, laica o eclesiástica, en tanto que la inmensa mayoría de la población, analfabeta, no ha dejado testimonios escritos. Pese a todo, no cabe ninguna duda de que en la conformación de las imágenes existen también expresiones de la mentalidad popular. Pero, en cualquier caso, las imágenes reflejan principalmente la mentalidad de los sectores sociales dominantes que, por otra parte, eran los que contaban con capacidad decisoria y que, en buena medida, marcaban el ritmo del acontecer histórico.

\subsection{Argumentos de carácter religioso}

Entre las acusaciones antijudías ocupan un lugar destacado las que tenían un componente de tipo religioso, no sólo por la peligrosidad que en sí mismas encerraban para la integridad física de la comunidad hebrea, sino también porque trascendian el mero nivel religioso y proyectaban sobre ella valores muy negativos que pasaban a formar parte de la imagen peyorativa del judío medieval.

La acusación más grave y más común era la que achacaba a los judíos el crimen de deicidio. Constantemente la Iglesia les recordaba su crimen nefando, y en numerosas poblaciones de señorío eclesiástico los judíos eran obligados al pago anual de treinta dineros por cabeza, en recuerdo de las treinta monedas con las que habían comprado a Judas la entrega de Jesucristo y para excusarse de la obligación de llevar sobre sus vestiduras las señales distintivas, principalmente la rodela de color bermejo.

La intervención de los judios en la crucifixión de Jesucristo les era imputada global y permanentemente, y daba lugar a otras acusaciones de índole religiosa o psicológica que los teólogos cristianos presentaban en sus tratados de apologética antijudía. Entre estas acusaciones destaca la crueldad, que tendría su más clara expresión en la saña con la que trataron a Cristo, así como a los Apóstoles y a los primeros discípulos. Numerosas escenas pictóricas y escultóricas de la Pasión representan con los rasgos iconográficos propios de los judíos - nariz larga y ganchuda, mirada torva, gorro o capirote cónico y puntiagudo, rodela sobre el vestido - a los personajes que flagelan y colocan en la cruz a Jesús, así como a otros que observan con complacencia el martirio o que se muestran en actitud jubilosa ante Cristo crucificado, con el fin de que no quede la menor duda de su participación activa en tan terrible 
acontecimiento ${ }^{19}$. Las escenas de la Pasión se multiplican en el arte cristiano desde fines del siglo XIII, expresando una violencia cada vez mayor por parte de los verdugos de Jesús, y siendo también cada vez más numerosos los judíos en ellas representados ${ }^{20}$.

La crueldad judaica se expresaría, asimismo, mediante imágenes impactantes que escenifican relatos histórico-legendarios, como aquéllas en las que un padre judio da muerte a su propio hijo - generalmente arrojándolo a un horno encendido - por haberse convertido al cristianismo, por asistir a misa y comulgar, o por cantar loas a la Virgen ${ }^{21}$. Otra indudable manifestación de la crueldad de los judíos, mezcla de ritual religioso y mágico, serían los crímenes rituales cometidos con niños cristianos con ocasión de la celebración de la Pascua, con el fin de rememorar la Pasión de Cristo y de utilizar la sangre del niño para la preparación de las mazzot ${ }^{22}$. No eran tampoco infrecuentes las leyendas y las escenas pictóricas que representaban a judíos azotando crucifijos, como escarnio de la Pasión.

El rechazo de Jesús como el Mesías anunciado en la Biblia y del dogma de la Santísima Trinidad motivaron la acusación contra los judíos de pertinacia y contumacia en la fe. Diversas obras de apologética antijudía hacian referencia a la ceguera de los judios, lo que les impedía reconocer en Jesús al Mesías esperado: son, entre otros escritos, los tratados

19 En una de las miniaturas que ilustran la cantiga $n^{2} 140$ de las Cantigas de Santa María, de Alfonso $X$ el Sabio, se representa una escena de la muerte de Jesucristo en la cruz, en la que aparecen siete personajes judíos que observan con profunda satisfacción el estado en el que se encuentra Jesús, así como el dolor de la Virgen Maria al pie de la cruz. Dichos personajes son figurados con los rasgos iconográficos propios de los judíos en el arte medieval: largas y pobladas barbas, narices prominentes y ganchudas, y gorros cónicos y puntiagudos cubriendo sus cabezas; uno de ellos sostiene en sus manos el martillo con el que fue clavado Cristo en la cruz, y otro la lanza con la que se le atravesó el costado. (Existe una buena reproducción de esta miniatura en MONUMENTOS HISTÓRICOS DE LA MÚSICA ESPAÑOLA, Cantigas de Santa María de Alfonso $X$ el Sabio. Madrid. Servicio de Publicaciones del Ministerio de Educación, 1979, pág. 61; acerca del valor de las miniaturas de las Cantigas de Santa María como fuente historiográfica resulta muy interesante el estudio de José Guerrero Lovillo, Las Cantigas. Estudio arqueológico de sus miniaturas. Madrid. Consejo Superior de Investigaciones Científicas, 1949).

20 Bernhard BlumenkRanz, Op. cit., págs. 88-104, y 111-112.

21 Este tipo de relatos se incluyen, entre otras obras, en la Primera Crónica General, en las Cantigas de Santa María de Alfonso X el Sabio (la cantiga $n^{2} 4$ narra la salvación milagrosa, por intercesión de la Virgen María, de un niño judío que fue arrojado por su padre a un horno encendido por haber asistido a misa y comulgar; la narración concluye con la muerte del padre en el horno), o en el Fortalitium fidei de fray Alonso de Espina.

${ }_{22}$ Las mazzot son unas tortas de pan ázimo o cenceño, es decir sin levadura, a modo de tortas aplastadas, que los judíos consumen durante la celebración de Pesah. Las mazzot constituyen uno de los elementos principales del séder o cena ritual de Pesah, y simbolizan las tortas que fueron preparadas a toda prisa, sin esperar a que fermentara la masa, por la salida apresurada de Egipto, según se narra en el Éxodo, XII, 34 y 39, y XIII, 5-10. 
Contra caecitatem iudaeorum, de fray Bernardo de Oliver, editado por Francisco Cantera ${ }^{23}$, y El libro de la sabiduría de Dios, de Alfonso de Zamora, editado por Federico Pérez Castro ${ }^{24}$. El mensaje principal que en estos tratados se transmite es que, pese a que Cristo se había manifestado a los judios antes que a ningún otro pueblo, éstos no lo habían reconocido como el Mesías por su ceguera y por su dureza de corazón.

Esta noción trascendió pronto al arte cristiano medieval y, consiguientemente, a la imagen del judío. La obstinación judaica en no reconocer en Cristo al Mesías anunciado en la Biblia se representaba, frecuentemente, mediante una figura de mujer, la Sinagoga, con los ojos cubiertos por una venda, que en ocasiones tenía la forma de una serpiente o de un escorpión para dar a entender que se trataba de una ceguera intencionada. La mujer presenta en ocasiones la cara descompuesta, los cabellos revueltos y la ropa desordenada, señales todas ellas de infamia y de ignorancia, y suele llevar en las manos una lanza o una caña rota para apoyarse, como símbolo de la decrepitud de la Ley antigua; junto a ella suelen aparecer, rotos en el suelo, algunos fragmentos de las Tablas de la Ley. Frente a ella, la representacón de la Ecclesia se hace mediante una mujer joven, frecuentemente coronada como reina, de rostro bello y victorioso, y que sostiene en sus manos una cruz como símbolo de la salvación, sobre la que se apoya vigorosamente ${ }^{25}$.

Estas representaciones de la Sinagoga y de la Ecclesia se exponían en los pórticos de las catedrales de ciudades que contaban con la presencia de una comunidad judía, lo que revela una clara finalidad propagandística, y es una manifestación más de la confrontación Sinagoga-Ecclesia ${ }^{26}$.

23 Francisco Cantera BuRgos, El tratado "Contra caecitatem iudaeorum" de fray Bernardo Oliver. Edición crítica y bibliografia, Madrid, 1965.

Del mismo autor, son también de interés los trabajos titulados «El Obispo Bernardo Oliver y la tradición manuscrita de un tratado Contra caecitatem iudaeorum", en Estudios Eclesiásticos, 34 (1960), págs. 413-418, y "Los manuscritos germánicos del tratado Contra caecitatem iudaeorum del obispo Bernardo Oliver", en Homenaje a Johannes Vincke. Madrid, Gaerres-Gesellschaft zur Pflege der Wissenschaft - Consejo Superior de Investigaciones Científicas, 1962-1963, págs. 251-264.

24 Federico Pérez CASTRO, El manuscrito apologético de Alfonso de Zamora. Respons. traducción y estudio de Séfer Hokmat Elohim por... Madrid. Consejo Superior de Investigaciones Científicas, 1950.

25 Son paradigmáticas a este respecto las figuras de la Sinagoga y de la Ecclesia de la portada meridional de la catedral francesa de Estrasburgo.

26 Véase al respecto Bernhard BlumenkRanz, Op. cit., págs. 58-66, y 105-115 (“Synagoga personifiées).

Del mismo autor, pueden también ser consultados los trabajos titulados aGéographie historique d'un théme de l'iconographie religieuse: les représentations de Synagoga en France", en Mélanges $R$. Crozet, Poitiers, 1966, vol. 2, págs. 1141-1157, y «La représentation de Synagoga dans les Bibles moralisées françaises du $13 \mathrm{e}$ au $15 \mathrm{e}$ siècles, en Proceedings of the Israel Academy of Sciences and Humanities, 5 (1970), págs. 70-91. 
En otras ocasiones la ceguera judaica es representada mediante un grupo de judíos que se tapan los oídos para no escuchar los argumentos de los cristianos, o que están dormidos ante los profetas anunciando la llegada del Mesías. Éste es también el significado que hay que dar a algunas representaciones de judíos privados de la palabra, de la vista o del oído, o a aquéllas otras en las que aparece un pequeño diablo encaramado en los hombros de la mujer que simboliza la Sinagoga y que le tapa los oídos o le lanza una flecha que se introduce en los ojos y le priva definitivamente de la vista ${ }^{27}$.

Idéntico propósito parece perseguir el artista cuando en algunas escenas de la Pasión, o en otras en las que aparecen Jesucristo y los Apóstoles, introduce a algunos personajes judíos que, tanto por la posición de sus cuerpos y cabezas como por los gestos de las manos, manifiestan una actitud contraria a Ellos.

La obstinación de los judíos en no admitir a Cristo como el Mesías anunciado en la Biblia era achacada por sus contemporáneos cristianos a otro rasgo considerado como propio del carácter judío: la terquedad. Su terca negativa a aceptar a Jesús como el Mesías les haría permanecer perpetuamente a la espera de la llegada del Mesías liberador.

Sin duda relacionada con esta supuesta peculiaridad del carácter judío se encuentra la frecuente alusión en la literatura española de épocas medieval y moderna a la paciencia de los judíos o de los judaizantes, que no se cansarian de esperar. Así, en un ingenioso epigrama de Alonso Jerónimo de Salas Barbadillo (1581-1635) titulado El caballero puntual, se dirige este autor a un judío de la siguiente manera:

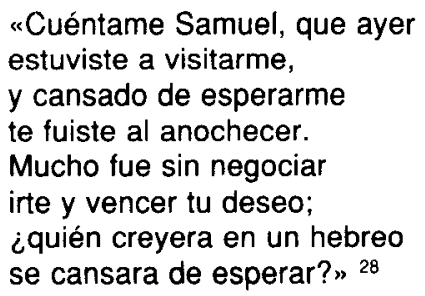

La acusación de obstinada y terca fidelidad a su Ley por parte de los judíos tiene también su reflejo en la literatura medieval hispana. Juan Ruiz, Arcipreste de Hita, expresa el férreo control que un padre ejercía sobre su hija de la siguiente manera:

27 Bernhard Blumenkranz, Op. cit,, págs. 51-54.

28 Citado por Julio Caro Baroja, Op. cit., vol. l, pág. 103. 


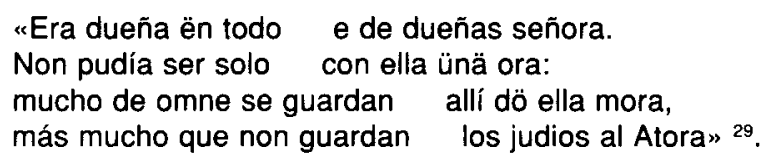

En definitiva, y como consecuencia de las anteriores acusaciones, el judío es considerado como un mal absoluto, un agente del diablo que está movido por las fuerzas del mal, que realiza actos crueles y que prepara complots contra los cristianos y el cristianismo.

En una de las Cantigas de Santa María, de Alfonso X el Sabio, un judío pregunta a los diablos por qué no hacían daño a los que profesaban su religión, contestándoles éstos que porque los judíos eran sus servidores:

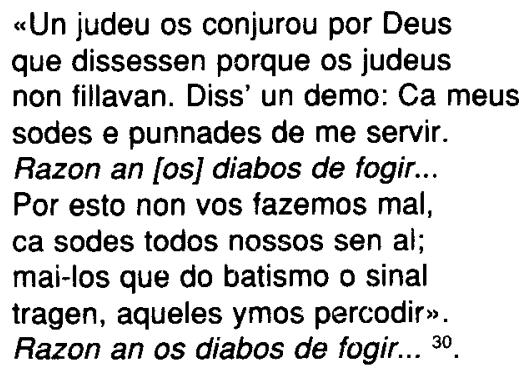

De este modo, no llama la atención que en representaciones plásticas en las que se escenifica de forma dicotómica el cielo y el infierno, los judíos sean situados en el infierno junto a los herejes; en otras ocasiones, algunos diablos son representados con los rasgos iconográficos propios de los judíos ${ }^{31}$. Como cualquier otra herejía, el judaísmo debía ser dominado por la Iglesia triunfante, por lo que en otras escenas pictóricas y escultóricas de época medieval se representa a algunos Apóstoles o a otras destacadas figuras del primitivo cristianismo pisando a personajes judíos que, con frecuencia, representan a rabíes ${ }^{32}$.

Desde el punto de vista escatológico, la tradición apocaliptica medieval liga a los judíos con el Anticristo, de forma que el nacimiento de éste se atribuye, frecuentemente, a una pareja de judíos de la tribu de Dan, de la

29 Juan Ruiz, Libro de Buen Amor. Edición crítica de Joan Corominas. Madrid. Editorial Gredos, S.A., 1973, estrofa 78, pág. 103.

30 Afonso X, o Sabio, Cantigas de Santa María. Editadas por Walter Mettmann. Vigo. Edicións Xerais de Galicia, S.A., 1981, 5 vols. (Tomo I, pág. 412).

31 Bernhard Blumenkranz, Op. cit., págs. 45-46.

32 Así, por ejemplo, en los capiteles del pórtico principal de la catedral de Évora (Portugal). 
que también se consideraba descendiente a Judas Iscariote. Por este motivo, en las miniaturas de alguna Vita Antechristi francesa de época medieval se representa el nacimiento del Anticristo mediante una escena que tiene como fondo la torre de Babilonia: un grupo de hombres y mujeres sobre cuyos vestidos lievan una rodela amarilla, signo distintivo de los judíos franceses, permanecen de pie ante el recién nacido, en torno al cual revolotean algunos demonios.

Así, pues, el pueblo judío es un pueblo maldito, y su maldad es, además, irreversible. Esta maldad se transfiere del individuo a las cosas que toca, especialmente los alimentos, que se volverían impuros ${ }^{33}$. En esta creencia radica la prohibición, común a muchas ciudades y villas hispanas, de que estuvieran juntos los mercados de cristianos y judios, así como de que aquéllos adquirieran productos alimenticios en el mercado de la judería. Junto a otras razones de índole económica o religiosa -estas prohibiciones tienen su origen en los cánones de algunos sínodos y concilios, como el concilio de Vienne de 1311-, resulta evidente el temor a un envenenamiento de los cristianos provocado por los judíos. Es éste un temor que forma parte del subconsciente colectivo, y que se manifestará en los diferentes ámbitos geo-históricos de la Europa occidental, especialmente con ocasión de las mortandades producidas por las epidemias de peste.

La perversidad judaica, que tenía un claro matiz religioso ligado al crimen de deicidio, traspasaría el ámbito individual y alcanzaría a toda la colectividad hebrea. Otras manifestaciones que evidenciarían dicha perversidad serían los crímenes rituales, la profanación de Hostias consagradas y el envenenamiento del agua de pozos, ríos y fuentes.

Desde los primeros decenios del siglo XIV se extendieron por toda la Europa occidental rumores que achacaban a los judíos y a los leprosos, confabulados, la autoría de algunas epidemias, mediante el envenenamiento del agua de pozos, ríos y fuentes con una fórmula mágica; la primera acusación documentada de esta índole tuvo lugar en Aquitania, en 1321. Las acusaciones se multiplicaron con motivo de la famosa Peste Negra de 1348, de forma que en muchas localidades la mortandad fue achacada a pociones maléficas preparadas por hechiceros judíos -en ocasiones se dice que procedentes de Toledo, la ciudad «mágica" por ex-

33 Puede consultarse sobre el particular el interesante estudio de Maurice KRIEGEL, "Un trait de psycologie sociale dans les pays méditerranéens du bas Moyen Âge: le juif comme intouchable", en Annales. Économies. Sociétés. Civilisations, mars-avril 1976, págs. 326-330. 
celencia a lo largo de toda la Edad Media-, dando lugar a asaltos contra las juderías ${ }^{34}$.

Por otra parte, la noticia más antigua sobre una acusación de crimen ritual en España es, posiblemente, la que recayó sobre los judíos de Biel (Zaragoza), quienes fueron acusados de la desaparición de una niña cristiana en el año 1294. Los casos se sucedieron a lo largo de los siglos XIV y $\mathrm{XV}, \mathrm{y}$ a fines de esta centuria tuvo lugar el más conocido de todos, el del Santo Niño de La Guardia (Toledo), que fue juzgado por el tribunal de la Inquisición de Ávila en 1491; este proceso dio lugar a una importante exacerbación de los ánimos antijudíos, que pudo influir en alguna medida en la promulgación del edicto de expulsión general del 31 de marzo de $1492{ }^{35}$.

Las acusaciones sobre crimenes rituales se remontan, al menos, a la Antigüedad clásica, y fueron lanzadas a lo largo de la Historia contra muy distintos pueblos, grupos humanos o facciones políticas, con el fin de procurar su desprestigio. Por lo que respecta en concreto a la acusación dirigida contra los judíos, junto a la imputación de asesinato y de escarnio a los principios más sagrados de la religión cristiana -el crimen ritual suponía una rememoración de la Pasión de Cristo llevada a cabo, generalmente, sobre un niño cristiano-, las acusaciones contenían también una importante carga de carácter mágico: se trataría de creencias supersticiosas relacionadas con sacrificios humanos, así como con el uso para prácticas mágicas de la sangre obtenida en dichos crímenes ${ }^{36}$.

El arte medieval, por su parte, ofrece abundantes ejemplos de escenas de crimen ritual, que serían el reflejo plástico de leyendas que se mantenían vivas en la conciencia colectiva.

Otra de las acusaciones que con mayor frecuencia fue lanzada contra los judíos a lo largo de la Baja Edad Media fue la de la profanación de Hostias consagradas. Este tipo de acusaciones pertenece a la tradición

34 Sobre este particular puede consultarse el documentado estudio de Amada LÓPEZ DE MENESES, "Una consecuencia de la peste negra en Cataluña: el pogrom de 1348", en Sefarad, XIX (1959), págs. $92-133$ y 321-365.

35 El proceso del Santo Niño de La Guardia fue estudiado por Fidel FITA y ColomÉ, "La verdad sobre el martirio del Santo Niño de La Guardia, ó sea el proceso y quema (16 de noviembre 1491) del judío Jucé Franco en Ávila», en Boletín de la Real Academia de la Historia, 11 (1887), págs. 7-135.

Es también interesante el epígrafe que le dedica Yitzhak BAER en su Historia de los Judios en la España Cristiana, Madrid, Altalena, 1981, 2 vols. (vol. II, págs. 621-638).

36 Para profundizar en el conocimiento de este tema puede acudirse al estudio, ya clásico, de V. MANZINI, L'omicidio rituale e i sacrifici umani, con particulari riguardo ale accuse contro gli ebrei. Torino, 1926, y al más reciente de M. DESPINA, "Las acusaciones de crimen ritual en España", en El Olivo, 9 (1979), págs. 48-70. 
oral y es muy similar en todos los casos: un judío roba o compra a un cristiano una Hostia consagrada con el fin de profanarla o de utilizarla en un ritual mágico, concluyendo la historia con un milagro. Las representaciones plásticas de estos acontecimientos son también frecuentes en todo el arte cristiano medieval ${ }^{37}$.

En el siglo Xv estuvo asimismo bastante extendida la creencia de que los médicos judios asesinaban a sus pacientes cristianos; esta acusación ponía en evidencia la decidida voluntad de los judíos de dañar a los cristianos, y añadía un grado más a su imagen de perversidad. Uno de los primeros judios que sufrieron esta acusación fue Mayr Alguadex, médico del rey Enrique III, quien fue acusado de su muerte en 1406.

En definitiva, ninguna duda cabía a fines de la Edad Media acerca de la maldad judaica. Según la línea de pensamiento agustiniano, los judíos eran tolerados simplemente por su condición humana, y su presencia se justificaba como testimonio permanente de la Pasión del Señor, como depositarios del Antiguo Testamento, y con la esperanza de lograr finalmente su conversión al cristianismo. El objetivo principal que habría de perseguirse en relación con los judios es su conversión, aunque para ello hubiera que vencer un obstáculo que parecía insuperable, como es su terquedad. Pero, entre tanto y como se indica textualmente en las disposiciones del concilio de Zamora de 1312

"por la su culpa muy descomunal, deben ser atados para siempre et en serviçio de los christianos et en onrra del nombre de Dios, por la ofensa et el menospreçio tan grande que fiçieron" ${ }^{38}$.

\subsection{Argumentos de carácter psicológico}

Diversos eran también los rasgos que definian la personalidad y el carácter del judío según la imagen peyorativa que del mismo fue conformándose a lo largo de la Edad Media.

37 El iemor a una incorrecta utilización de los objetos sagrados es común a todas las creencias y a todos los tiempos. No cabe duda de que la difusión del culto a la Eucaristía, principalmente a partir de los siglos $x \|$ y xill, fue unida a crecientes temores y rumores acerca del robo de Hostias consagradas en las iglesias para su utilización en rituales de brujería o, en el mejor de los casos, como talismanes (véase Richard KIECKHEfER, La magia en la Edad Media, Barcelona, Crítica, 1992, págs. 89-90).

38 José AMADOR DE LOS Rios, Historia social, política y religiosa de los judios de España y Portugal. Madrid, 1876, 3 vols. (en concreto, vol. II, pág. 563). 
En primer lugar la soberbia que, junto a su terquedad y ceguera, les impediría reconocer en Cristo al Mesías esperado. Los judíos eran acusados por sus contemporáneos cristianos de soberbia y orgullo de carácter, acusación que es también compartida por algún autor hispano-hebreo, como Shelomoh ben Verga. De este modo, cuando ben Verga especula acerca de las causas del odio del pueblo contra los judíos, señala entre ellas en primer lugar la soberbia y el ansia de poder, que les llevaría a olvidar su condición de desterrados y de siervos, de forma que

"los judíos se vanaglorian y si uno tiene doscientos oros, enseguida viste trajes de seda y a sus hijos recamados, cosa que no hacen los nobles aunque tengan una renta anual de mil doblones. Por esto se les imputan cargos con el propósito de que sean desterrados del reino" ${ }^{39}$.

Los ejemplos de acusaciones contra los judíos de soberbia y orgullo son numerosos en la literatura castellana de fines de la Edad Media. Andrés Bernáldez, cronista de los Reyes Católicos, afirma que los judíos

“...tenian presunción de soberbia, que en el mundo no había mejor gente, ni más discreta, ni más aguda, ni más honrada que ellos, por ser del linaje de las tribus e medio de Israel. En quanto podían adquirir honra, oficios reales, favores de Reyes e señores, algunos se mezclaron con fijos e fijas de caballeros christianos viejos con sobra de riquezas que se hallaron bien aventurados por ello, por los casamientos y matrimonios que ansí ficieron, que quedaron en la Inquisición por buenos christianos e con mucha honra» ${ }^{40}$.

Con frecuencia también los judíos son presentados como traidores, senalándose como hito referencial por excelencia para esta acusación su colaboración en el año 711 con los musulmanes invasores del reino visigodo ${ }^{41}$. Es éste un argumento que quizá tiene su primera fundamentación documental en la crónica hispano-musulmana titulada Ajbar machmu'ah, obra de fines del siglo $x$ o de principios del $x l^{42}$; esta crónica hace referencia a la participación de tropas judías, al mando de Kaula al-

\footnotetext{
39 Shelomoh IEN VERGA, La Vara de Yehudah (Sefer Sebet Yehudah). Introducción, traducción y notas por María José Cano. Barcelona. Riopiedras Ediciones, 1991, pág. 44.

40 Andrés Bernáldez, Historia de los Reyes Católicos don Fernando y doña Isabel. Crónicas de los Reyes de Castilla, III. Biblioteca de Autores Españoles, LXX. Madrid. Atlas, 1953, vol. III, capítulo XLIII, pág. 600.

41 Parecida denuncia fue dirigida también en época medieval contra los judíos franceses, quienes fueron acusados de colaborar con los normandos en los ataques que éstos lanzaron contra la costa atlántica de Francia en la segunda mitad del siglo IX.

42 Su título completo es Ajbar machmu'ah fi fath al-Andalus, y fue traducida y anotada por Emilio Lafuente y Alcántara en su Colección de obras arábigas de Historia y Geografía (t. I), Madrid, Real Academia de la Historia, 1867.
} 
Yehudí, junto a los invasores, y a la constitución de guarniciones judías en algunas ciudades como Granada, Córdoba, Sevilla y Toledo, lo que permitió a los musulmanes una mayor libertad de movimientos en su avance hacia el norte de la Península Ibérica ${ }^{43}$. Entre los mozárabes se conservó viva la memoria de la colaboración de los judíos en la «pérdida de España», lo que tiene su reflejo en algunas crónicas de época medieval ${ }^{44}$. Todavía en el siglo XV se recordaba la traición de los judíos en algunos textos como la Sentencia-Estatuto de Pero Sarmiento (1449) o el Fortalitium fidei de fray Alonso de Espina (1459).

Aunque estos hechos se hubieran producido mucho tiempo antes, el recuerdo de los mismos permaneció vivo a lo largo de toda la Edad Media, lo que tampoco resulta extraño en un mundo como el medieval en el que las representaciones mentales estaban saturadas de anacronismos. Para el hombre de la Edad Media las imágenes que transmitían el arte y los relatos historiográficos y literarios habían sucedido en el pasado pero seguian existiendo en el momento presente; por lo tanto, el mensaje que se recibía era atemporal ${ }^{45}$. Esta concepción, típicamente medieval, es de una gran relevancia al analizar la acusación de deicidio lanzada contra los judíos, pues los cristianos de época medieval consideraban que el delito de los judíos seguía vigente en su tiempo; les faltaba, por tanto, la necesaria perspectiva histórica para distinguir entre los judíos que habían condenado a muerte a Jesucristo y sus contemporáneos.

Otro de los rasgos definitorios del carácter de los judíos sería la cobardía, en abierta contraposición al valor que definiría al combatiente cristiano.

Teniendo en cuenta el sistema de valores propio de los tiempos medievales, la cobardía era uno de los mayores defectos que podía achacarse a un humbre, y que de ningún modo se compensaba con otro tipo de aptitudes intelectuales que, como la astucia o la inteligencia, sí se reconocían a los judíos. Aunque común a todo el Occidente europeo, este sistema de valores se veía reforzado en la España medieval por el ideal de cruzada, que fue conformado, en buena medida, por la empresa reconquistadora ${ }^{46}$.

43 José Amador de los Ríos, Op. cit., vol. I, págs. 105-108.

44 Por ejemplo, en el Chronicon Mundi, de Lucas de Tuy, obra concluida en el año 1236, y en la Historia Gothica (Rerum in Hispania gestarum Chronicon) de Rodrigo Jiménez de Rada.

45 José María Monsalvo Antón, Op. cit., pág. 119.

46 José María Monsalvo Antón, Op. cit., pág. 120. 
Aunque es difícil saber qué fundamento existe - si es que hay alguno- para que se achacara a los judíos la cobardía de carácter ${ }^{47}$, desde luego no existe la menor duda de que en toda la Europa mediterránea era considerada como un rasgo propio y definitorio del carácter de los judíos quienes, según la creencia popular, serían asustadizos, tímidos y cobardes. El obispo de Burgos Alonso de Cartagena hace constar en su Defensorium Unitatis Christianae (1449) que toda persona que era algo tímida recibía el calificativo de judío ${ }^{48}$.

Como otras expresiones conformadoras de la imagen del judío medieval, también la acusación de cobardía trascendió a la literatura. En su célebre obra El Corbacho, también conocida como Reprobación del amor mundano, en la que Alfonso Martínez de Toledo, más conocido como el Arcipreste de Talavera (1398-1470), hace una sátira misógina de finalidad didáctico-moral, equipara la falta de carácter de los judíos a la de las mujeres y los clérigos:

«Por ende, las mugeres muchas vezes toman tanta osadía, syn miedo alguno del onbre, que se tyenen por dicho: 'Muger so, non me fará nada, non me ferirá: non sacará arma para mí, que soy muger, que le correría todo el mundo sy tal fiziese o cometiese: que para mujer, judío nin abad non deve onbre mostrar rrostro, nin esfuerço, nin cometer a ferir, nin sacar armas: que son cosas vençidas e de poco esfuerço" ${ }^{49}$.

Asimismo, cuando el Arcipreste de Talavera se refiere a las cualidades amatorias de los hombres flemáticos dice lo siguiente:

«Ay otros onbres que son flemáticos, los quales son para arte de amar los más áviles e convenientes del mundo: éstos son primeramente perezosos -toma quanto a lo primero- para comienço de amar; son muy cobardes, más que judíos — nota lo segundo-para ser amados" ${ }^{50}$.

A la difusión de la creencia popular en la cobardía de carácter de los judíos pudo contribuir, y no en pequeña medida, el hecho de que los hebreos

47 En el Shebet Yehudah (capítulo 7, pág. 40 de la ed. de María José Cano), Shelomoh ben Verga la pone en relación con la maldición divina contenida en el Levítico (XXV1, 36):

"A quienes de vosotros sobrevivan infundiré tal pusilanimidad en sus corazones en las tierras de sus enemigos, que el ruido de una hoja agitada los pondrá en fuga, y huirán como se huye de la espada, y caerán sin que nadie los persiga".

4 Albert SICROFF, Les controverses des status de pureté de sang en Espagne du XVe au XVIle siècles, Paris, 1960 (citado por José Ma MONSALVO, Op. cit., pág. 119).

49 Alfonso MARTinez DE TOLEDO, Arcipreste de Talavera. Edición de Marcella Ciceri. Madrid. Espasa Calpe, col. “Austra|», 1990, parte II, capítulo VIII, págs. 201-202.

so Alfonso MartíneZ DE Toledo, Arcipreste de Talavera, parte II, capítulo IX, pág. 253. 
estuvieran exentos de participar en actividades bélicas. Pero este hecho, incontestable ${ }^{51}$, no obedecería a una falta de aptitud de los judíos para el combate, ni mucho menos a una supuesta cobardía, sino al temor que infundiría que pudieran estar armados unos potenciales enemigos de los cristianos, a los que, además, se les achacaba el delito de traición en otros tiempos. No hay tampoco que perder de vista que los judíos tenían terminantemente prohibido portar armas, lo que se encuentra en relación con las disposiciones de Cortes y con las ordenanzas concejiles que les prohibian llevar signos externos de lujo (vestidos, adornos), con el fin de que no pudieran ser confundidos con miembros del estamento nobiliario.

El judío es caracterizado, así pues, como soberbio y orgulloso, traidor y cobarde; si estaba adornado de algunas cualidades, éstas eran la inteligencia y la sagacidad. Cuando en el capítulo séptimo del Shebet Yehudah Shelomoh ben Verga se refiere a las excelentes condiciones que los judios tuvieron en la Antigüedad para la guerra, por su inteligencia y sagacidad para concebir y desarrollar planes bélicos, señala que eso no debe llamar la atención, pues

«...Es reconocido por todos que los judíos son los más inteligentes y astutos de todos los pueblos" 52 .

Esta astucia les era también reconocida por los cristianos ${ }^{53}$, si bien, generalmente, con un matiz claramente peyorativo; de este modo, la «sotileza" de los judios en el desempeño de los oficios que ejercían era tal que provocaba la ruina de las personas y de los pueblos, por lo que en las Cortes de Valladolid de 1385 se les prohibia que tuvieran cargos ${ }^{54}$. Andrés Bernáldez definía a los judíos como

"gente muy sotil, y gente que vivía comúnmente de muchos logros y osuras con los chrestianos, y en poco tiempo muchos pobres de ellos eran ricos" ${ }^{55}$.

\footnotetext{
51 A fines del siglo x.v, y debido a que no intervenian en las operaciones bélicas de la Guerra de Granada, los judíos de Castilla fueron obligados a satisfacer, junto con los mudéjares, el impuesto denominado "servicio de los castellanos de oro" (véase el estudio de Miguel Ángel LADERo QUESADA, "Las juderías de Castilla según algunos "servicios" fiscales del siglo XV", en Sefarad, XXXI (1971), págs. 249-264.

52 Selomoh IBN Verga, La Vara de Yehudah (Sefer Sebet Yehudah), capítulo 7, pág. 38 de la ed. de María José Cano.

53 Es muy gráfico a este respecto el refrán castellano que dice "Ni judio necio ni liebre perezosa".

(Luis Martínez Kleiser, Refranero General Ideológico Español. Madrid. Editorial Hernando, 1989, 3. ${ }^{\text {a }}$ reimpresión, pág. 394).

54 José María Monsalvo Antón, Op. cit., pág. 120.

55 Andrés BERNÁLDEZ, Op. cit., capítulo CXII, pág. 653.
} 
En la España de los siglos XV y XVI era opinión común que los judíos y los judeoconversos eran personas que sembraban la discordia en los organismos de los que formaban parte, por su espíritu maquinador, su soberbia y su avaricia sin límites.

$Y$ esto permite enlazar con otro de los tipos de argumentos señalados por Julio Caro Baroja como conformadores de la imagen peyorativa del judio medieval: los de carácter económico.

\subsection{Argumentos de carácter económico}

Es sobradamente conocida la acusación de usureros que pesa sobre los judíos, y que lleva aparejadas otras de no menor gravedad, como la avaricia, la astucia perversa, el egoísmo, o el engaño, consideradas todas ellas como propias de quienes se dedicaban a tratos dinerarios.

La acusación de usura lanzada contra los judíos es un tema recurrente en épocas medieval y moderna, desde los más diversos puntos de vista didáctico, literario o teológico-doctrinal. Lo más peligroso para la comunidad hebrea eran las exageraciones y los bulos que corrían acerca de las riquezas desmedidas de sus integrantes, así como sobre su afán insaciable de dinero, que se satisfacería a costa de los más humildes, obligados a acudir a sus préstamos dinerarios en condiciones muy duras. Así, se convertía en rasgo universal de la comunidad judía algo que sólo sería representativo de un pequeño sector de la misma ${ }^{56}$.

Los judíos eran también acusados de rechazar los trabajos más duros y dedicarse sólo a aquéllos que requerían menores esfuerzos y que les garantizaban unos mayores y más fáciles ingresos. Suficientemente expresivas de esta imagen del judío son, nuevamente, las palabras de Andrés Bernáldez:

"Y comúnmente por la mayor parte eran gentes logreras, é de muchas artes y engaños, porque todos vivian de oficios holgados, y en comprar $y$

56 Véanse sobre este particular los estudios de Francisco CANTERA BURGos, “La usura judía en Castilla", en Ciencia Tomista, XLIII (1931), págs. 5-26; David Romano VentuRA, "Prestadores judios en los estados hispánicos medievales", en Estudios Mirandeses, VIII (1988), págs. 117-126 (reimp. en David Romano VENTURA, De historia judía hispánica, Universidad de Barcelona, 1991, págs. 421-430), y "Los judíos hispánicos y el préstamo", en Proceedings of the Eleventh World Congress of Jewish Studies. Division B: The History of the Jewish People. Volume 1: Second Temple period to Modern times. Jerusalem, World Union of Jewish Studies, 1994, págs. 91-98; y Entique Cantera MONTENEgro, "Pleitos de usura en la diócesis de Osma en el último tercio del siglo XV», en Anuario de Estudios Medievales, 12 (1982), págs. 597-622. 
vender no tenían conciencia para con los christianos. Nunca quisieron tomar oficios de arar ni cavar, ni andar por los campos criando ganados, ni lo enseñaron a sus fijos, salvo oficios de poblados, y de estar asentados ganando de comer con poco trabajo" ${ }^{57}$.

En otro lugar de su obra Bernáldez se refiere también a los judíos en los siguientes términos:

«...que estos judíos de Castilla, en cuyo tiempo fue este edicto del Rey y de la Reyna, estaban heredados en las mejores ciudades, villas e lugares, e en las tierras más gruesas e mejores, y por la mayor parte moraban en las tierras de los señorios, e todos eran mercaderes e vendedores, e arrendadores de alcabalas e rentas de achaques, y hacedores de señores, tundidores, sastres, zapateros, curtidores, zurradores, tejedores, especieros, buhoneros, sederos, plateros, y de otros semejantes oficios; que ninguno rompía la tierra, ni era labrador, ni carpintero, ni abañiles, sino todos buscaban oficios holgados, e de modos de ganar con poco trabajo ${ }^{58}$.

Algunos refranes castellanos se refieren también a la escasa o nula actitud de los judíos hacia el trabajo. Pese a que puede tratarse de paremias surgidas con posterioridad a la expulsión de los judíos de España, no cabe ninguna duda de que son un reflejo de una mentalidad en relación con la minoría hebrea que perduró largo tiempo después de su desaparición física de suelo hispano. Son, entre otros:

"No es el judío para el trabajo, ni el trabajo para el judío",

0

“Judio y trabajar, no se pueden concordar» 59.

A los ojos de sus contemporáneos cristianos, los judíos pasaban por ser los principales beneficiarios de la economía monetaria, que se había desarrollado en los reinos hispanos, como en las restantes áreas de la Europa occidental, a lo largo de la Baja Edad Media. El nuevo poder del dinero fue causa de una alteración sustancial no sólo en los modos de actuación económicos, sino también en las relaciones sociales tradicionales. Esta nueva situación aparece fielmente reflejada en la literatura castellana de los siglos XIV y XV, de forma que aquellos autores que se muestran más recelosos ante las importantes transformaciones económicas y

57 Andrés Bernáldez, Op. cit., capítulo XLIII, pág. 600 .

58 Andrés Bernáldez, Op. cit., capítulo CXII, pág. 653.

59 Luis Martinez Kleiser, Refranero General Ideológico Español, pág. 394. 
sociales que estaban teniendo lugar se manifiestan también especialmente críticos para con los judíos. Probablemente sea el canciller Pero López de Ayala (1332-1407) la figura más representativa de esta toma de postura; en El Libro Rimado de Palacio, en las estrofas 244-263, condena durísimamente la rapacidad de los más poderosos de la sociedad, quienes se valdrían de los judíos para la recaudación de los tributos que se repartían sobre los más humildes:

245

“Alli vienen judios, que estan aparejados para beuer la sangre de los pobres cuitados: presentan sus escriptos, que tienen conçertados e prometen sus joyas e dones a priuados.

\section{7}

Alli fazen judios el su rrepartimiento sobre el pueblo que muere por mal defendimiento, e ellos luego apartan entre si medio cuento, que han de auer priuados, qual ochenta, qual çiento.

\section{0}

Dizen luego al rrey: "Por çierto vos tenedes judios seruidores e merçed les faredes; ca vos pujan las rrentas por çima las paredes: otorgad gelas, señor, ca buen rrecabdo avredes".

\section{1}

"Señor —dizen judios-, seruiçio vos faremos: tres cuentos mas que antaño, por ellas vos daremos, e buenos fiadores lianos vos prometemos con estas condiçiones, que escriptas vos traemos".

\section{2}

Aquellas condiçiones, Dios sabe quales son: para el pueblo mesquino, negras commo carbon. "Señor - dizen priuados-, faredes grant rrazon de les dar estas rrentas ençima gualardon".

$$
254
$$

Despues daquesto llegan, don Abrahan e don Simuel, con sus dulçes palabras, que vos paresçen miel, e fazen una puja sobre los de Isrrael, que monta en todo el rregno cuento e medio de fiel.

262

E tienen para esto judios muy sabidos para sacar los pechos e los nueuos pedidos; non lo dexan por lagrimas que oyan, nin gemidos; demas, por las esperas, aparte son seruidos. 
Aun para esto peor lo vi fazer:

en las rrentas del rrey suelen parte tener, por que non se les pueda el pobre defender de les dar lo que piden o todo lo perder, 60 .

Los rabinos y algunos intelectuales judeo-españoles del siglo XV eran conscientes del peligro que acarreaba para la comunidad hebrea la difusión de esta imagen de riqueza y lujo desmedido de sus miembros, por lo que continuamente recomendaban un retorno a la humildad y a la modestia en sus actitudes internas y, especialmente, en sus comportamientos externos. Selomoh ben Verga consideraba que la práctica de la usura era una de las causas principales del odio visceral que los cristianos sentían hacia los judíos:

"La segunda razón para odiarlos es porque los judíos, cuando vinieron al reino de nuestro señor, eran pobres y los cristianos ricos, y ahora sucede to contrario. Pues el judio es inteligente e ingenioso para conseguir su provecho, además se ha enriquecido grandemente con las artes de la usura. Vea nuestro señor que las tres cuartas partes de los campos y heredades de Sefarad están en manos de los judios, por la onerosa usura que ejercen" ${ }^{61}$

En definitiva, los judíos eran considerados colectivamente como usureros, lo que tenía su fundamento en la dedicación de algunos de los miembros más destacados de las comunidades hebreas a la práctica del préstamo con interés, así como a otras actividades socio-profesionales relacionadas con el dinero, como el arrendamiento y la recaudación de rentas. El estereotipo del judío usurero era muy peligroso para la comunidad hebrea, pues no sólo se acusaba a los judíos de robar y engañar a los cristianos, sino, además, de ejercer sobre éstos un dominio económico manifiesto. Las quejas contra la usura judaica fueron constantes a lo largo de los siglos XIV y $x v$ en todas las sesiones de Cortes ${ }^{62}$, lo que es un reflejo indudable de lo hondo que había calado la imagen peyorativa del judío usurero.

Del mismo modo, algunos refranes castellanos hacen referencia a la avaricia de los judíos, así como a su poca conciencia cuando se trata de asuntos dinerarios. Son algunos de ellos los siguientes:

60 Pero López de Ayala, Rimado de Palacio. Edición crítica, introducción y notas de Germán Orduna. Pisa. Giardini Editori, 1981, 2 vols. (vol. I, págs. 174-177).

61 Selomoh IBn Verga, La Vara de Yehudah (Sefer Sebet Yehudah), capítulo 7, pág. 44 de la ed. de María José Cano.

62 Véase el estudio de Pilar LEÓN TELlo, "Legislación sobre judíos en las Cortes de los antiguos reinos de León y Castilla", en Proceedings of the Fourth World Congress of Jewish Studies. Jerusalem, 1965, vol. 2, págs. 55-63. 
"Judío, poca vergüenza, poca conciencia, y mucha diligencia",

0

«Duerme don Sem Tob, mas su dinero no» ${ }^{63}$.

\subsection{Argumentos de carácter físico}

Como ya se ha hecho notar anteriormente, el arte medieval ofrece multitud de datos acerca de la imagen que de los judíos tenían sus contemporáneos cristianos. No en vano, las imágenes plásticas gozaron a lo largo de la Edad Media de una capacidad adoctrinadora que nunca más han tenido en igual medida; los mensajes se transmiten de forma más simple y esquemática que en los textos escritos y, por tanto, también con mucha mayor claridad. De este modo, las representaciones pictóricas y escultóricas -en particular las tablas y relieves expuestos en iglesias y catedrales- fueron un instrumento idóneo para la difusión de un ideario antijudío.

El arte medieval codificó una imagen propia del judío, utilizando para ello determinados rasgos específicos: barba larga, patillas muy prolongadas a modo de tirabuzones ${ }^{64}$, nariz prominente y ganchuda, y ciertos elementos de la indumentaria, como el capirote cónico cubriendo la cabeza y la rodela sobre el hombro derecho. Esta figura gráfica sería utilizada con frecuencia como mejor sistema para representar algunos vicios que se achacaban comúnmente a los judíos, como la avaricia, la usura, la hipocresía, la traición, o el delito de herejía; para el artista de la Edad Media era más sencillo representar estos vicios a través de un modelo iconográfico perfectamente fijado, como era el del judío, pues así el pueblo los asociaría con los hebreos. Del mismo modo, las representaciones de escenas del Antiguo y del Nuevo Testamento eran ocasiones propicias para la difusión de un mensaje antijudío: el usurero judío medieval aparecía representado en los mercaderes que Jesucristo expulsa del Templo; las frecuentes escenas de la Pasión servían para transmitir la imagen de la dureza y la crueldad de los judíos para con Cristo; y no eran raras tampoco escenas en las que un judío o la figura de mujer que representaba a la Sinagoga aparecían relacionados con el diablo, con el infierno o con las bestias inmundas que habitaban en éste.

63 Luis MARtinez KLEISER, Refranero General Ideológico Español, pág. 394.

64 Son las $P$ e'ot, o largas mechas, a modo de tirabuzones, que descienden desde la sien a lo largo de las mejillas, y que todavía se utilizan en la actualidad en algunos círculos ortodoxos del judaísmo. Su mayor difusión se produjo a partir de los siglos XVI y XVII en las comunidades ashkenazies de la Europa central. 
Como hemos tenido ocasión de comprobar a lo largo de este trabajo, todas las acusaciones lanzadas contra los judíos, y que conformaban su imagen peyorativa, tuvieron su representación plástica, pictórica o escultórica. No cabe ninguna duda de que el mensaje antijudio se endurecía considerablemente mediante su representación gráfica; del mismo modo, su éxito estaba plenamente garantizado teniendo en cuenta la facilidad con la que eran comprendidos los modelos iconográficos por un pueblo mayoritariamente analfabeto.

A través del análisis de numerosas representaciones de judíos en tallas, tablas y miniaturas de época medieval resulta evidente la voluntad del artista por resaltar su aspecto desagradable y antipático. A este fin, se exageran la longitud de las narices y su marcado aspecto ganchudo, el tamaño y fealdad de los dientes, y sus miradas malévolas, contribuyendo a propagar la idea de que el judío era la representación misma del mal.

Pero las imágenes gráficas de los judios permiten comprobar que el odio que se sentía hacia ellos era, principalmente, de carácter religioso y no étnico. Como acertadamente ha observado Bernhard Blumenkranz, los rasgos que caracterizan al judío medieval serían adquiridos y no hereditarios; en definitiva, el artista no pretendería expresar unas características propiamente étnicas, sino una idea teoiógica directamente relacionada con la idea de la salvación. Por este motivo, en tanto que los personajes contrarios al mensaje de Cristo aparecen generalmente representados con los rasgos característicos del estereotipo judío, que se acentúan en quienes intervienen en el martirio de Jesús, tanto los Apóstoles como los primeros discípulos no presentan dichos rasgos pese a que étnicamente eran también hebreos. $Y$ algo similar sucede con los niños judíos que son martirizados por sus padres por asistir a misa y comulgar, y en los que su conversión al cristianismo habría borrado los rasgos desagradables del aspecto físico de los judíos ${ }^{65}$.

\section{CONCLUSIÓN}

Como hemos tenido ocasión de comprobar, las representaciones imaginarias de los judíos en época medieval giran, principalmente, en torno a tres grandes cuestiones: a la acusación de deicidio, imputada a la comunidad hebrea de forma colectiva y permanente, y que se tradujo, tanto

Bernhard BlumenkaAnz, Op. cit,, págs. 24-25. 
en el arte religioso como en el profano, en la transformación del judío en una especie de representación simbólica del verdugo; a la negación de Cristo como el Mesías anunciado en la Biblia, que dio lugar a la acusación de infidelidad a Dios, que se consideraba a su vez causada por la terquedad y la ceguera de los judíos; y a la perversidad judaica que, con sus diversas manifestaciones - crueldad, soberbia, egoísmo, avaricia, astucia perversa, traición-, hacía del pueblo hebreo una especie de personificación del mal.

No obstante, y como certeramente señala Danièle Sansy, al tratar estas cuestiones hay que evitar el riesgo de caer en una simplificación abusiva, que sea el resultado de una sistematización exagerada, pues no puede perderse de vista que existen algunas similitudes entre la imagen del judio y las representaciones, asimismo peyorativas, de otros distintos grupos sociales de excluidos ${ }^{66}$.

Pero si por ésta y por otras razones de similar índole el tratamiento de este tipo de cuestiones exige extremar el rigor y la cautela, parece suficientemente demostrado que el modeio constitutivo de la imagen del judio presenta ya en época bajomedieval una mayor homogeneidad entre distintas áreas geo-históricas que la que puede observarse en relación con la imagen de otros diversos grupos de la marginalidad social - religiosa. Asimismo es la figura del judío la que concentra un mayor número de rasgos y características negativas, resaltándose con insistencia, de forma muy particular, su radical enemistad hacia el cristianismo y los cristianos.

Por otra parte, resulta también evidente que la imagen del judío conformada en época medieval no constituye un retrato realista; al contrario, mediante un análisis detenido de la misma es fácil apreciar la distancia existente entre la realidad de la minoría hebrea - suficientemente conocida ya, al menos en sus líneas más generales- y la percepción que de ella tenía la mayoría cristiana. Es ésta una razón más que obliga a tratar con suma cautela todo lo relativo al mundo de la imagen del judío, por su indiscutible subjetivismo; pero al mismo tiempo, y como contrapartida, el estudio de las imágenes tiene un enorme interés para el mejor conocimiento del lugar que la minoría hebrea ocupaba en la conciencia colectiva de la mayoría cristiana, así como de la evolución de la ideología dominante en relación con los judíos.

66 Danièle SANSY, “Jalons pour une iconographie médiévale du juif", en Xudeus e Conversos na Historia (Carlos Barros ed.), vol. I, págs. 135-169. 
En cualquier caso, y retomando las palabras de la introducción, la imagen del judío fue también motivadora de determinados comportamientos y tomas de actitud hacia la minoría hebrea, por lo que en diferentes momentos tuvo asimismo un indiscutible protagonismo histórico.

Por todo ello, se hace preciso profundizar en el estudio de las cuestiones que aquí quedan meramente planteadas. 